Wahana Didaktika Vol. 17 No.1 Januari 2019 : 70-83

\title{
PENINGKATAN KEMAMPUAN MENENTUKAN IDE POKOK DAN \\ MELENGKAPI PARAGRAF DALAM MEMBACA PEMAHAMAN DENGAN METODE PEMBELAJARAN KOOPERATIF TIPE STUDENT TEAMS ACHIEVEMENT DIVISION
}

\author{
Oleh: Redo Andi Marta \\ (Dosen Universitas Mahaputra Muhammad Yamin, Padang) \\ Email: redoandimarta@rocketmail.com
}

\begin{abstract}
Abstrak
Penelitian ini dilatarbelakangi karena tingkat kemampuan membaca siswa rendah. Salah satu di antaranya penerapan metode pembelajaran yang digunakan guru belum bervariasi. Metode pembelajaran yang sering diterapkan oleh guru yakni metode ceramah yang masih berpusat pada guru. Oleh karena itu, peneliti memberikan solusi untuk meningkatkan kemampuan membaca siswa khususnya kemampuan membaca pemahaman dengan metode pembelajaran kooperatif tipe Student Teams Achievement Division (STAD) siswa kelas XI SMA Adabiah Padang. Jenis penelitian ini adalah penelitian tindakan kelas dengan subjek penelitian siswa kelas XI IPS 6 SMA Adabiah Padang yang berjumlah 45 orang. Berdasarkan deskripsi dan analisis data dapat disimpulkan kemampuan membaca pemahaman meliputi pertama menentukan ide pokok paragraf pada siklus 1 berada kualifikasi baik menjadi meningkat kualifikasi baik sekali pada siklus 2 dan kedua, melengkapi paragraf pada siklus 1 berada kualifikasi cukup menjadi meningkat baik pada siklus 2. Dengan demikian, penggunaan metode pembelajaran kooperatif tipe Student Teams Achievement Division (STAD) membawa pengaruh yang sangat besar dalam menerapkan materi membaca pemahaman khususnya menentukan ide pokok dan melengkapi paragraf.
\end{abstract}

Kata Kunci: Ide pokok, membaca pemahaman, Student Teams Achievement Division

\section{IMPROVEMENT OF ABILITY TO DETERMINE THE IDEA IDEAS AND COMPLETE PARAGRAPHS IN READING UNDERSTANDING USING THE TYPE OF COOPERATIVE LEARNING METHODS OF ACHIEVEMENT TEAM STUDENTS}

\begin{abstract}
This research is motivated because the level of students' reading ability is low. One of them the application of teaching methods used by teachers has not varied. Teaching methods that are often applied by the teacher is a lecture method that is still centered on the teacher. Therefore, researchers provide solutions to improve students' reading ability, especially reading comprehension with cooperative learning method of Student Teams Achievement Division (STAD) type XI SMA Adabiah Padang. This type of research is a classroom action research with the subjects of students of class XI IPS 6 SMA Adabiah Padang, amounting to 45 people. Based on the description and analysis of the data can be concluded
\end{abstract}


the ability of reading comprehension includes first determine the main idea of paragraphs in cycle 1 is well qualified to be improved qualifications both in cycle 2 and second, completing the paragraph in cycle 1 is qualified enough to be improved both in cycle 2. Thus, the use of cooperative learning method of Student Teams Achievement Division (STAD) has great influence in applying comprehension comprehension material especially to determine the main idea and complete the paragraph.

Keywords: Key Ideas, Reading Comprehension, Student Teams Achievement Division

\section{A. PENDAhuluan}

Keterampilan membaca pemahaman tidaklah sebuah kegiatan yang pasif. Kegiatan ini berada pada peringkat yang lebih tinggi. Membaca pemahaman bukan sekedar memahami tanda baca dan struktur ejaan saja, melainkan pula memahami, menerima, menolak, membandingkan, dan meyakini pendapatpendapat yang ada dalam bacaan. Membaca pemahaman inilah yang dibina dan dikembangkan secara bertahap di sekolah (Razak, 2001).

Keterampilan membaca pemahaman teks karya sastra ataupun non sastra sangat penting dan di sekolah guru mampu menciptakan suasana pembelajaran membaca yang menarik, menyenangkan, dan tidak membosankan bagi siswanya, karena menuntut siswa agar lebih giat membaca bukanlah suatu kehendak yang mudah dilaksanakan. Hal tersebut akan terwujud apabila diberikan arahan yang dapat membangkitkan kecintaan siswa terhadap membaca. Untuk itu, peneliti melakukan kegiatan observasi dan wawancara dengan guru bahasa Indonesia kelas XI SMA Adabiah Padang.

Berdasarkan observasi awal dan hasil wawancara dengan guru bahasa Indonesia kelas XI SMA Adabiah Padang, peneliti menemukan beberapa kendala pembelajaran keterampilan membaca khususnya membaca pemahaman. Siswa sulit memahami informasi penting atau gagasan pokok dalam bacaan, siswa sering ragu-ragu dalam menentukan ide pokok atau kalimat utama dalam suatu paragraf, dan siswa masih ada yang salah dalam melengkapi paragraf menjadi paragraf yang padu. Selain itu, pembelajaran keterampilan membaca kurang diminati dan dianggap sesuatu yang membosankan. Berdasarkan observasi awal 
dan hasil wawancara yang telah peneliti lakukan di SMA Adabiah Padang, dapat disimpulkan bahwa permasalahan tersebut terjadi karena beberapa faktor. Di antaranya, dalam proses belajar mengajar khususnya membaca yang sedang berlangsung guru menerapkan metode pembelajaran yang belum bervariasi. Umumnya didominasi dengan metode ceramah.

Hal ini menyebabkan siswa memperoleh sedikit waktu untuk membaca di kelas. Metode-metode yang inovatif dan kreatif dalam pembelajaran membaca, terutama membaca pemahaman penting untuk diterapkan. Salah satu metode yang tepat dengan menggunakan metode pembelajaran kooperatif. Metode pembelajaran ini akan menimbulkan minat siswa dalam membaca pemahaman serta memberikan kesempatan kepada siswa untuk berinteraksi sesamanya (Asma, 2008).

Salah satu tipe metode pembelajaran kooperatif adalah Student Teams Achievement Divisons (selanjutnya, ditulis STAD). Tipe ini melatih siswa belajar dan diskusi secara berkelompok. Tiap kelompok memiliki kemampuan yang heterogen, yakni kemampuan tinggi, sedang, dan rendah. Dengan demikian, siswa dapat terlatih melakukan tanya jawab dan diskusi dalam memecahkan masalah tentang materi yang diberikan oleh guru. Berdasarkan hal tersebut, penelitian ini penting dilakukan dengan judul "Peningkatan Kemampuan Menentukan Ide Pokok dan Melengkapi Paragraf dalam Membaca Pemahaman dengan Metode Pembelajaran Kooperatif Tipe Student Teams Achievement Division Siswa Kelas XI SMA Adabiah Padang”.

\section{B. METODOLOGI PENELITIAN}

Jenis penelitian ini adalah penelitian tindakan kelas (classroom action reseach) dengan menggunakan pendekatan mixing yaitu gabungan antara pendekatan kualitatif dan kuantitatif (Whardani, 2007) .Karakteristik utama dalam penelitian tindakan kelas adalah bersifat siklus, artinya penelitian tindakan kelas terikat oleh siklus-siklus. Setiap siklus terdiri perencanaan, pemberian tindakan, pengamatan, dan refleksi. Subjek penelitian adalah siswa kelas XI IPS 6 SMA Adabiah Padang yang berjumlah 45 orang yang terdiri dari 25 siswa laki-laki dan 
20 siswa perempuan. Instrumen yang digunakan dalam penelitian ini yaitu lembaran tes objektif, lembaran observasi, dan angket. Langkah-langkah yang ditempuh untuk menganalisis data dalam penelitian ini adalah sebagai berikut. Pertama, mengecek dan mengolah data dari pretest membaca pemahaman. Kedua, membandingkan nilai tes membaca pemahaman pretest terhadap siklus1. Ketiga, membandingkan nilai tes membaca pemahaman pada siklus 1 dan siklus 2 . Keempat, tes dianalisis dengan menggunakan rumus untuk mengolah skor menjadi nilai digunakan rumus.

\section{HASIL PENELITIAN DAN PEMBAHASAN}

Hasil-hasil penelitian dideskripsikan berdasarkan siklus-siklus yang telah dilaksanakan. Siklus penelitian ini terdiri dari dua pelaksanaan. Pelaksanaan setiap siklus tergantung pada keaktifan siswa dan perubahan yang dicapai.

\section{Siklus Pertama}

Kompetensi dasar yang dipelajari pada siklus ini adalah membaca pemahaman dengan metode pembelajaran kooperatif menggunakan tipe STAD. Sebelum memulai siklus I diadakan pretes membaca pemahaman.

Tabel 1. Kemampuan Membaca Pemahaman pada Pretes

\begin{tabular}{|c|c|c|l|}
\hline No & Nilai Siswa & Frekuensi & Ketuntasan \\
\hline 1. & $23-63$ & 33 orang & Tidak tuntas \\
\hline 2. & $66-76$ & 12 orang & Tuntas \\
\hline
\end{tabular}

Gambaran siswa dalam membaca pemahaman tergolong kurang. Hal ini dapat dilihat dari sampel yang memperoleh nilai belum mencapai Kriteria Ketuntasan Minimal (KKM) 65 SMA Adabiah Padang. Kegiatan penelitian tindakan kelas ini dilaksanakan dalam empat tahap yaitu perencanaan, tindakan, observasi, dan refleksi. Dalam penelitian ini digunakan tiga instrumen untuk melihat keberhasilan penerapan siklus yaitu lembaran tes objektif, lembar observasi kegiatan pembelajaran, dan angket respon siswa terhadap pembelajaran.

\section{1) Kemampuan Menentukan Ide Pokok}

Skor tertinggi yang diperoleh siswa adalah 5 dan skor terendah 1. Perolehan skor secara lengkap untuk indikator menentukan ide pokok paragraf, yaitu (1) siswa yang memperoleh skor 5 berjumlah 2 siswa $(4,44 \%)$, (2) siswa yang 
memperoleh skor 4 berjumlah 7 siswa $(15,55 \%)$, (3) siswa yang memperoleh skor 3 berjumlah 10 siswa (22,22\%), (4) siswa yang memperoleh skor 2 berjumlah 14 siswa $(31,11 \%)$, (5) siswa yang memperoleh skor 1 berjumlah 12 siswa $(26,66 \%)$.

Berdasarkan data yang sudah diperoleh dapat dikelompokkan skor, nilai, dan klasifikasi nilai kemampuan membaca pemahaman melalui metode pembelajaran kooperatif tipe STAD siswa kelas XI IPS 6 SMA Adabiah Padang. Untuk lebih jelasnya mengenai tingkat kemampuan membaca pemahaman kelas XI IPS 6 SMA Adabiah Padang dengan metode pembelajaran kooperatif tipe STAD untuk indikator menentukan ide pokok. Berikut pembahasan data siklus pertama.

Tingkat penguasaan tertinggi yang dicapai siswa adalah 100 dan terendah 20. Gambaran tingkat kemampuan membaca pemahaman siswa kelas XI IPS 6 SMA Adabiah Padang melalui metode pembelajaran kooperatif tipe STAD untuk indikator menentukan ide pokok paragraf, yaitu (1) siswa yang tingkat penguasaannya 100 berjumlah 3 orang $(6,66 \%)$, (2) siswa yang tingkat penguasaannya 80 berjumlah11 orang $(24,44 \%)$, (3) siswa yang tingkat penguasaannya 60 berjumlah 12 orang (26,66\%), (4) siswa yang tingkat penguasaannya 40 berjumlah 13 orang $(28,88 \%)$, dan (5) siswa yang tingkat penguasaannya 20 berjumlah 6 orang $(13,33 \%)$. Setelah tingkat penguasaan membaca pemahaman siswa diketahui, langkah selanjutnya adalah menafsirkan kemampuan membaca pemahaman siswaberdasarkan rata-rata hitung (M).

Tabel 2. Distribusi Frekuensi Kemampuan Menentukan Ide Pokok

\begin{tabular}{|c|c|c|c|}
\hline No. & $\mathbf{X}$ & $\mathbf{F}$ & $\mathbf{F X}$ \\
\hline 1 & 100 & 3 & 330 \\
\hline 2 & 8 & 1 & 880 \\
\hline 3 & 6 & 1 & 720 \\
\hline 4 & 4 & 1 & 40 \\
\hline 5 & 2 & 6 & 120 \\
\hline & & $\mathbf{N}$ & $\mathbf{2 5 4 0}$ \\
\hline
\end{tabular}

Berdasarkan rata-rata $(\mathrm{M})$ yang diperoleh dapat disimpulkan bahwa tingkat kemampuan membaca pemahaman dengan metode pembelajaran kooperatif tipe STAD siswa kelas XI IPS 6 SMA Adabiah Padang untuk indikator menentukan ide pokok paragraf berada pada kategori cukup karena berada pada rentang 56- 
65\% pada skala 10. Langkah selanjutnya adalah mengkualifikasikan tingkat kemampuan membaca pemahaman dengan metode pembelajaran kooperatif tipe STAD siswa kelas XI IPS 6 SMA Adabiah Padang untuk indikator menentukan ide pokok paragraf berdasarkan skala 10 dapat dikelompokkan menjadi tiga, yaitu: (1) kualifikasi sempurna (S) sebanyak 3 orang (6,66\%), (2) kualifikasi baik (B) sebanyak 11 orang (24,44\%), (3) kualifikasi cukup (C) sebanyak 12 orang (26,66\%), (4) kualifikasi kurang (K) sebanyak 13 orang (28,88\%), dan (5) kualifikasi buruk (Bu) sebanyak 6 orang $(13,33 \%)$.

\section{2) Kemampuan Melengkapi Paragraf}

Skor tertinggi yang diperoleh siswa adalah 5 dan skor terendah 1. Perolehan skor secara lengkap untuk indikator melengkapi paragraf, yaitu (1)siswa yang memperoleh skor 5 berjumlah 4 siswa $(8,88 \%)$, (2) siswa yangmemperoleh skor 4 berjumlah 10 siswa (22,22\%), (3) siswa yang memperolehskor 3 berjumlah 17 siswa $(37,77 \%)$, (4) siswa yang memperoleh skor 2berjumlah 9 siswa (20\%), (5) siswa yang memperoleh skor 1 berjumlah siswa $5(11,11 \%)$.

Berdasarkan data yang sudah diperoleh dapat dikelompokkan skor, nilai, dan klasifikasi nilai kemampuan membaca pemahaman melalui metode pembelajaran kooperatif tipe STAD siswa kelas XI IPS 6 SMA Adabiah Padang. Untuk lebih jelasnya mengenai tingkat kemampuan membaca pemahaman kelas XI IPS 6 SMA Adabiah Padang dengan metode pembelajaran kooperatif tipe STAD untuk indikator melengkapi paragraf. Berikut pembahasan data siklus pertama.

Tingkat penguasaan tertinggi yang dicapai siswa adalah 80 dan terendah 20 . Gambaran tingkat kemampuan membaca pemahaman siswa kelas XI IPS 6 SMA Adabiah Padang melalui metode pembelajaran kooperatif tipe STAD untuk indikator melengkapi paragraf, yaitu (1) siswa yang tingkat penguasaannya 80 berjumlah 2 orang $(4,44 \%)$, (2) siswa yang tingkat penguasaannya 60 berjumlah 15 orang $(33,33 \%)$, (3) siswa yang tingkat penguasaannya 40 berjumlah 15 orang $(33,33 \%)$, dan (4) siswa yang tingkat penguasaannya 20 berjumlah 13 orang $(28,88 \%)$. 
Setelah tingkat penguasaan membaca pemahaman siswa diketahui, langkah selanjutnya adalah menafsirkan kemampuan membaca pemahaman siswa berdasarkan rata-rata hitung $(\mathrm{M})$.

Tabel 4. Distribusi Frekuensi Kemampuan Melengkapi Paragraf

\begin{tabular}{|c|c|c|c|}
\hline No. & $\mathbf{X}$ & $\mathbf{F}$ & FX \\
\hline 1 & 80 & 2 & 160 \\
\hline 2 & 60 & 15 & 900 \\
\hline 3 & 40 & 15 & 600 \\
\hline 4 & 20 & 13 & 260 \\
\hline & & $\mathrm{N}=45$ & 1920 \\
\hline
\end{tabular}

Dari data tabel 4 tersebut dapat diperoleh rata-rata hitung (M) sebesar 42,66\%. Berdasarkan rata-rata (M) yang diperoleh dapat disimpulkan bahwa tingkat kemampuan membaca pemahaman dengan metode pembelajaran kooperatif tipe STAD siswa kelas XI IPS 6 SMA Adabiah Padang untuk indikator melengkapi paragraf berada pada kategori kurang karena berada pada rentang 36-45\% pada skala 10. Langkah selanjutnya adalah mengkualifikasikan tingkat kemampuan membaca pemahaman dengan metode pembelajaran kooperatif tipe STAD siswa kelas XI IPS 6 SMA Adabiah Padang untuk indikator melengkapi paragraf berdasarkan skala 10 dapat dikelompokkan menjadi tiga, yaitu: (1) kualifikasi baik (B) sebanyak 2 orang (4,44\%), (2) kualifikasi cukup (C) sebanyak 15 orang (33,33\%), (3) kualifikasi kurang (K) sebanyak 15 orang $(33,33 \%)$, (4) kualifikasi buruk $(\mathrm{Bu})$ sebanyak 13 orang $(28,88 \%)$.

\section{a. Tahap Observasi}

Pada pembelajaran ini juga akan dibahas tentang penggunaan angket respon siswa terhadap pembelajaran. Angket ini digunakan untuk memperoleh data tentang pelaksanaan pembelajaran kemampuan siswa menentukan kesimpulan bacaan dan menentukan susunan kalimat dalam membaca pemahaman melalui metode pembelajaran kooperatif tipe STAD. Hasil respon siswa terhadap pembelajaran tersebut dapat dideskripsikan sebagai berikut. Pertama, 31 siswa $(68,88 \%)$ berada pada kualifikasi lebih dari cukup, menyatakan senang terhadap pembelajaran membaca pemahaman melalui metode kooperatif tipe STAD. Kedua, 26 siswa $(57,77 \%)$ berada pada kualifikasi cukup, menyatakan metode pembelajaran ini sangat memotivasi siswa untuk 
belajar membaca pemahaman. Ketiga, 28 siswa (62,22\%) berada pada kualifikasi cukup, menyatakan metode ini dapat membantu siswa dalam belajar. Keempat, 36 siswa (80\%) berada pada kualifikasi baik, menyatakan dengan metode ini siswa memperoleh nilai yang meningkat. Berdasarkan deskripsi di atas dapat disimpulkan secara keseluruhan rata- rata hasil angket respon siswa pada siklus I terhadap pembelajaran adalah $604,41: 10=60,441 \%$ berada pada kualifikasi cukup.

\section{b. Tahap Refleksi}

Refleksi adalah kegiatan menganalisis hasil pengamatan peneliti bersama guru pendamping, untuk menentukan sejauh mana metode pembelajaran kooperatif telah berhasil meningkatkan kemampuan siswa dalam membaca pemahaman. Berdasarkan pelaksanaan siklus I, dapat disimpulkan bahwa penerapan membaca pemahaman melalui metode pembelajaran kooperatif tipe STAD mampu meningkatkan kemampuan siswa dalam membaca pemahaman. Selain itu, pembelajaran membaca pemahaman melalui metode kooperatif tipe STAD ini cukup diminati siswa. Namun, masih perlu dilakukan perbaikan untuk mendapatkan hasil yang lebih memuaskan.

\section{Siklus Kedua}

Kegiatan penelitian tindakan kelas pada siklus 2 ini dilaksanakan sama dengan siklus I terdiri dari empat tahap yaitu tahap perencanaan, tahap pelaksanaan, tahap observasi, dan tahap refleksi. Dalam penelitian pada siklus 2 ini juga digunakan tiga instrumen untuk melihat keberhasilan penerapan siklus 2 yaitu lembar tes objektif, lembar observasi, dan angket respon siswa.

Kompetensi dasar yang dipelajari pada siklus ini adalah membaca pemahaman dengan metode pembelajaran kooperatif menggunakan tipe STAD. Sebelum memulai siklus 2 diadakan tes siklus I membaca pemahaman. Ringkasan hasil tes siklus 1 sebagai berikut.

Tabel 6. Kemampuan Membaca Pemahaman pada Tes Siklus 1

\begin{tabular}{|c|c|c|c|}
\hline No & Nilai siswa & Frekuensi & Ketuntasan \\
\hline 1. & $46-63$ & 32 siswa & Tidak tuntas \\
\hline 2. & $66-80$ & 13 siswa & Tuntas \\
\hline
\end{tabular}


Gambaran siswa dalam membaca pemahaman tergolong kurang. Hal ini dapat dilihat dari sampel yang memperoleh nilai belum mencapai Kriteria Ketuntasan Minimal (KKM) 65 SMA Adabiah Padang. Kegiatan penelitian tindakan kelas ini dilaksanakan dalam empat tahap yaitu perencanaan, tindakan, observasi, dan refleksi. Dalam penelitian ini digunakan tiga instrumen untuk melihat keberhasilan penerapan siklus yaitu lembaran tes objektif, lembar observasi kegiatan pembelajaran, dan angket respon siswa terhadap pembelajaran.

\section{1) Kemampuan Menentukan Ide Pokok}

Skor tertinggi yang diperoleh siswa adalah 5 dan skor terendah 1. Perolehan skor secara lengkap untuk indikator menentukan ide pokok paragraf, yaitu (1) siswa yang memperoleh skor 5 berjumlah 1 siswa $(2,22 \%)$, (2) siswa yang memperoleh skor 4 berjumlah 12 siswa (26,66\%), (3) siswa yang memperoleh skor 3 berjumlah 25 siswa $(55,55 \%)$, (4) siswa yang memperoleh skor 2 berjumlah 5 siswa $(11,11 \%)$, (5) siswa yang memperoleh skor 1 berjumlah 2 siswa $(4,44 \%)$.

Berdasarkan data yang sudah diperoleh dapat dikelompokkan skor, nilai, dan klasifikasi nilai kemampuan membaca pemahaman melalui metode pembelajaran kooperatif tipe STAD siswa kelas XI IPS 6 SMA Adabiah Padang. Untuk lebih jelasnya mengenai tingkat kemampuan membaca pemahaman kelas XI IPS 6 SMA Adabiah Padang dengan metode pembelajaran kooperatif tipe STAD untuk indikator menentukan ide pokok paragraf. Berikut pembahasan data siklus 2 .

Tingkat penguasaan tertinggi yang dicapai siswa adalah 100 dan terendah 20. Gambaran tingkat kemampuan membaca pemahaman siswa kelas XI IPS 6 SMA Adabiah Padang melalui metode pembelajaran kooperatif tipe STAD untuk indikator menentukan ide pokok paragraf, yaitu (1) siswa yang tingkat penguasaannya 100 berjumlah 1 orang $(2,22 \%)$, (2) siswa yang tingkat penguasaannya 80 berjumlah 12 orang $(26,66 \%)$, (3) siswa yang tingkat penguasaannya 60 berjumlah 24 orang $(53,33 \%)$, (4) siswa yang tingkat penguasa annya 40 berjumlah 5 orang $(11,11 \%)$, dan (5) siswa yang tingkat penguasaannya 
20 berjumlah 2 orang $(4,44 \%)$ Setelah tingkat penguasaan membaca pemahaman siswa diketahui, langkah selanjutnya adalah menafsirkan kemampuan membaca pemahaman siswa berdasarkan rata-rata hitung $(\mathrm{M})$.

\section{Tabel 7. Distribusi Frekuensi Kemampuan Menentukan Ide Pokok}

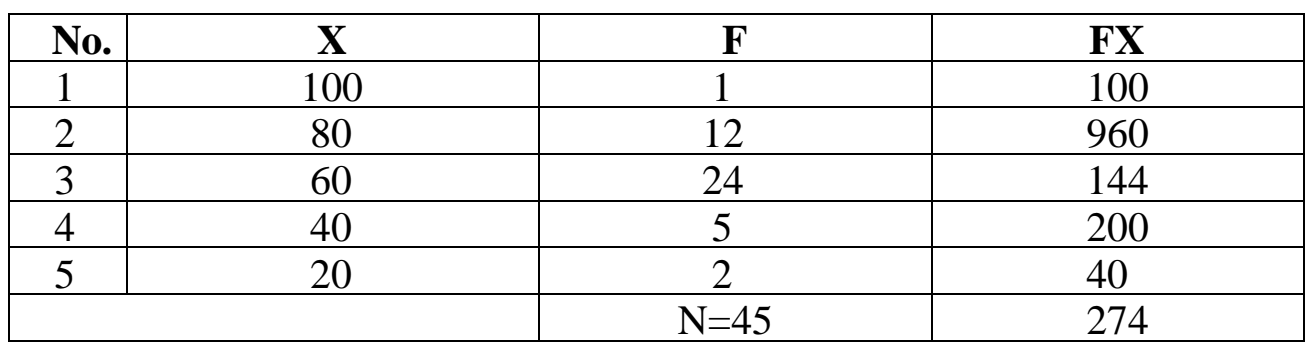

Dari data tabel 7 tersebut dapat diperoleh rata-rata $\mathrm{h}$ itung $(\mathrm{M})$ sebesar $68,88 \%$. Berdasarkan rata-rata $(\mathrm{M})$ yang diperoleh dapat disimpulkan bahwa tingkat kemampuan membaca pemahaman dengan metode pembelajaran kooperatif tipe STAD siswa kelas XI IPS 6 SMA Adabiah Padang untuk indikator menentukan ide pokok paragraf berada pada kategori lebih dari cukup karena berada pada rentang 66-75\% pada skala 10. Langkah selanjutnya adalah mengkualifikasikan tingkat kemampuan membaca pemahaman dengan metode pembelajaran kooperatif tipe STAD siswa kelas XI IPS 6 SMA Adabiah Padang untuk indikator menentukan ide pokok paragraf berdasarkan skala 10 dapat dikelompokkan menjadi lima, yaitu: (1) kualifikasi sempurna (S) sebanyak 1 orang (2,22\%), (2) kualifikasi baik (B)sebanyak 12 orang (26,66\%), (3) kualifikasi cukup (C) sebanyak 24 orang (53,33\%), (4) kualifikasi kurang (K) sebanyak 5 orang (11,11\%), dan (5) kualifikasi buruk (Bu) sebanyak 2 orang $(4,44 \%)$.

\section{2) Kemampuan Melengkapi Paragraf}

Skor tertinggi yang diperoleh siswa adalah 5 dan skor terendah 1. Perolehan skor secara lengkap untuk indikator melengkapi paragraf, yaitu (1)siswa yang memperoleh skor 5 berjum lah 3 siswa $(6,66 \%)$, (2) siswa yang 48 memperoleh skor 4 berjumlah 29 siswa $(64,44 \%)$, (3) siswa yang memperoleh skor 3 berjumlah 12 siswa $(26,66 \%)$, (4) siswa yang memperoleh skor 2 berjumlah 1 siswa (2,22\%), (5) siswa yang memperoleh skor 1 berjumlah 0 siswa (0\%). 
Berdasarkan data yang sudah diperoleh dapat dikelompokkan skor, nilai, dan klasifikasi nilai kemampuan membaca pemahaman melalui metode pembelajaran kooperatif tipe STAD siswa kelas XI IPS 6 SMA Adabiah Padang. Untuk lebih jelasnya mengenai tingkat kemampuan membaca pemahaman kelas XI IPS 6 SMA Adabiah Padang dengan metode pembelajaran kooperatif tipe STAD untuk indikator melengkapi paragraf. Berikut pembahasan data siklus 2 .

Tingkat penguasaan tertinggi yang dicapai siswa adalah 100 dan terendah 40. Gambaran tingkat kemampuan membaca pemahaman siswa kelas XI IPS 6 SMA Adabiah Padang melalui metode pembelajaran kooperatif tipe STAD untuk indikator melengkapi paragraf, yaitu (1) siswa yang tingkat penguasaannya 100 berjumlah 3 orang $(6,66 \%)$, (2) siswa yang tingkat penguasaannya 80 berjumlah 28 orang $(62,22 \%)$, (3) siswa yang tingkat penguasaanya 60 berjumlah 12 orang $(26,66 \%)$, (4) siswa yang tingkat penguasaannya 40 berjumlah 2 orang $(4,44 \%)$. Setelah tingkat penguasaan membaca pemahaman siswa diketahui, langkah selanjutnya adalah menafsirkan kemampuan membaca pemahaman siswa berdasarkan rata-rata hitung $(\mathrm{M})$.

Tabel 9. Distribusi Frekuensi Kemampuan Melengkapi Paragraf

\begin{tabular}{|c|c|c|c|}
\hline No & $\mathbf{X}$ & $\mathbf{F}$ & FX \\
\hline 1 & 100 & 3 & 300 \\
\hline 2 & 80 & 28 & 1760 \\
\hline 3 & 60 & 12 & 720 \\
\hline 4 & 40 & 2 & 80 \\
\hline & & $\mathrm{N}=45$ & 3340 \\
\hline
\end{tabular}

Dari data tabel 9 tersebut dapat diperoleh rata-rata $\mathrm{h}$ itung (M) sebesar $74,22 \%$. Berdasarkan rata-rata (M) yang diperoleh dapat disimpulkan bahwa tingkat kemampuan membaca pemahaman dengan metode pembelajaran kooperatif tipe STAD siswa kelas XI IPS 6 SMA Adabiah Padang untuk indikator melengkapi paragraf berada pada kategori lebih dari cukup karena berada pada rentang 66-75\% pada skala 10. Langkah selanjutnya adalah mengkualifikasikan tingkat kemampuan membaca pemahaman dengan metode pembelajaran kooperatif tipe STAD siswa kelas XI IPS 6 SMA Adabiah Padang untuk indikator melengkapi paragraf berdasarkan skala 10 dapat dikelompokkan 
menjadi empat, yaitu: (1) kualifikasi sempurna (S) sebanyak 3 orang $(6,66 \%)$, (2) kualifikasi baik (B)sebanyak 28 orang (62,22\%), (3) kualifikasi cukup (C) sebanyak 12 orang (26,66\%), (4) kualifikasi kurang (K) sebanyak 2 orang $(4,44 \%)$. Untuk lebih jelasnya pengelompokkan tingkat kemampuan membaca pemahaman dengan metode pembelajaran kooperatif tipe STAD siswa kelas XI IPS 6 SMA Adabiah Padang untuk indikator melengkapi paragraf dapat dilihat pada tabel berikut ini.

Tabel 10. Kualifikasi Kemampuan Melengkapi Paragraf

\begin{tabular}{|c|l|c|c|c|c|}
\hline No & \multicolumn{1}{|c|}{ Kualifikasi } & $\begin{array}{c}\text { Tingkat } \\
\text { Penguasaan }\end{array}$ & Nilai & Frekuensi & Persentase \\
\hline 1 & Sempurna & $96-100 \%$ & 100 & 3 & $6,66 \%$ \\
\hline 2 & Baik sekali & $86-95 \%$ & - & - & - \\
\hline 3 & Baik & $76-85 \%$ & 80 & 28 & $62,22 \%$ \\
\hline 4 & Lebih dari cukup & $66-75 \%$ & - & - & - \\
\hline 5 & Cukup & $56-65 \%$ & 60 & 12 & $26,66 \%$ \\
\hline 6 & Hampir cukup & $46-55 \%$ & - & - & - \\
\hline 7 & Kurang & $36-35 \%$ & 40 & 3 & $6,66 \%$ \\
\hline 8 & Kurang sekali & $26-36 \%$ & - & - & - \\
\hline 9 & Buruk & $16-25 \%$ & 40 & 2 & $4,44 \%$ \\
\hline 10 & Buruk sekali & $0-15 \%$ & - & - & - \\
\hline & & Jumlah & & 45 & $100 \%$ \\
\hline
\end{tabular}

Berdasarkan hasil tes siklus 2, siswa sudah mengalami peningkatan dalam membaca pemahaman. Apabila dibandingkan dengan hasil ringkasan siklus 1, siswa yang mengalami ketuntasan hanya 13 orang, sedangkan apabila dibandingkan hasil ringkasan pada tes siklus 2 terjadi peningkatan siswa yang mengalami ketuntasan sekitar 43 siswa $(95,55)$ serta telah mencapai Kriteria Ketuntasan Minimal (KKM).

\section{a. Tahap Observasi}

Observasi ini dilaksanakan dengan dua cara yaitu lembar observasi dan angket respon siswa terhadap pembelajaran pada akhir siklus 2 . Untuk penelitian ini observasi dilakukan oleh guru bahasa Indonesia selaku kolaborasi dengan mengisi format yang telah disediakan selama proses belajar mengajar berlangsung. Hasil observasi tersebut dapat dideskripsikan sebagai berikut. Pertama, siswa yang mengerjakan tugas dengan antusias ada 27 orang $(60 \%)$ berada pada kualifikasi cukup. Kedua, siswa yang termotivasi untuk 
mengikuti proses belajar mengajar dengan serius ada 29 orang $(64,44 \%)$ berada pada kualifikasi cukup. Ketiga, siswa yang aktif menanggapi pertanyaan, baik dari guru maupun dari siswa lain ada 31 orang $(68,88 \%)$ berada pada kualifikasi lebih dari cukup. Keempat, siswa yang aktif melakukan tanya jawab dengan guru ada 34 orang $(75,55 \%)$ berada pada kualifikasi lebih dari cukup. Kelima, siswa yang senang mengikuti pembelajaran membaca pemahaman dengan metode pembelajaran kooperatif menggunakan tipe STAD ada 39 orang $(86,66 \%)$ berada pada kualifikasi baik sekali. Keenam, siswa yang aktif mengikuti diskusi kelompok ada 26 orang $(57,77 \%)$ berada pada kualifikasi cukup. Ketujuh, siswa yang aktif dalam menjawab hasil diskusi ada 27 orang $(60 \%)$ berada pada kualifikasi cukup. Berdasarkan deskripsi tersebut dapat disimpulkan secara keseluruhan rata-rata hasil observasi adalah 536,62:7 = $76,66 \%$ berada pada kualifikasi baik.

Berdasarkan deskripsi di atas dapat disimpulkan secara keseluruhan ratarata hasil angket respon siswa pada siklus 2 terhadap pembelajaran adalah $876,63: 10=87,663 \%$ berada pada kualifikasi baik sekali. Kesimpulan kemampuan membaca pemahaman melalui metode pembelajaran kooperatif tipe STAD siswa kelas XI IPS6 SMA Adabiah Padang pada siklus 2 adalah $(876,63: 10)=87,663 \%$ berada pada kualifikasi baik sekali. Tindakan ini telah mencapai Kriteria Ketuntasan Minimal (KKM 65\%). Oleh sebab itu, tidak perlu lagi diadakan siklus berikutnya (siklus 3).

\section{b. Tahap Refleksi}

Hasil pengamatan peneliti bersama guru pendamping dilakukan setelah proses belajar mengajar berakhir, dalam kesempatan ini hasil temuan dan hasil dari pengamatan dibahas secara bersama. Refleksi pada siklus 2 ini mencakup terhadap (1) perencanaan pembelajaran; (2) pelaksanaan pembelajaran; (3) evaluasi pembelajaran; dan (4) hasil pemahaman tentang pembelajaran membaca. Latihan-latihan yang diberikan guru melalui beberapa contoh, penanganan pada hambatan dan kesulitan belajar siswa dapat diberikan secara intensif telah menambah wawasan siswa untuk lebih dapat menjawab soal-soal 
yang diberikan. Secara umum pembelajaran telah terlaksana dengan baik dan terjadi peningkatan kemampuan siswa dalam membaca pemahaman

\section{SIMPULAN}

Berdasarkan hasil pengolahan data tes penelitian dan pembahasan dapat disimpulkan hal sebagai berikut pertama, Metode pembelajaran kooperatif menggunakan Tipe STAD dapat meningkatkan kemampuan siswa menentukan ide pokok paragraf dalam membaca pemahaman dari kualifikasi baik menjadi kualifikasi baik sekali. Metode pembelajaran kooperatif menggunakan Tipe STAD dapat meningkatkan kemampuan siswa melengkapi paragraf dalam membaca pemahaman dari kualifikasi cukup menjadi kualifikasi baik.

\section{DAFTAR PUSTAKA}

Asma, Nur. (2008). Model Pembelajaran Kooperatif. Padang: UNP Press.

Razak, Abdul. (2001). Membaca Pemahaman: Teori dan Aplikasi Pengajaran. Pekanbaru: Autografika.

Whardani, Igak dkk. (2007). Penelitian Tindakan Kelas. Jakarta: Universitas Terbuka. 